\title{
GIVING VOICE: THE USE OF INTERACTIVE THEATRE AS PROFESSIONAL DEVELOPMENT IN HIGHER EDUCATION TO REDUCE ALIENATION OF MARGINALIZED GROUPS
}

\author{
Carol J. Maples \\ Dr. Barbara N. Martin, Dissertation Supervisor
}

\begin{abstract}
This qualitative study focused on the use of Interactive Theatre as professional development in higher education to give voice to the marginalized. The researcher viewed the study through the lens of Critical Race Theory which emphasizes the power of storytelling to reduce alienation of marginalized groups who find themselves invisible and silent.

The study population consisted of the leader of an Interactive Theatre program used for professional development, faculty and graduate teaching assistants who had participated in the program, and members of the Interactive Theatre troupe. The setting was a large Midwest university. Data collection methods included audio-recorded interviews and observations of individuals and a focus group, observation of an Interactive Theatre presentation, and document analysis. Through data analysis, two themes emerged which showed an awakening to issues associated with diversity and empowerment to address those issues were results of having participated in the Interactive Theatre program.

Implications of this inquiry for practice in education could impact both K-12 institutions and higher education institutions as they address the issues of diversity and giving voice to the marginalized, thus creating truly inclusive campus climates.
\end{abstract}

